\title{
COMMENTS
}

\section{Running the Caucus-Race: Prevailing Parties and Fee Shifting under ERISA}

\author{
Da-Wai Hu†
}

[T]hey began running when they liked, and left off when they liked, so that it was not easy to know when the race was over. However, when they had been running half an hour or so, ... the Dodo suddenly called out "The race is over!", and they all crowded round it, panting, and asking, "But who has won?"1

The Employee Retirement Income Security Act of 1974 ("ERISA") ${ }^{2}$ is a comprehensive federal law regulating the private employee benefit system. ${ }^{3}$ Congress enacted ERISA to address concerns that abuses in the management of pension plans caused the wrongful denial of benefits to workers. ${ }^{4}$ The enactment of ERISA provided for a means to ensure that benefits promised to workers would be paid. ${ }^{5}$ Congress hoped that ERISA would meet this goal "by

$\dagger$ B.A. 1996, Northwestern University; J.D. Candidate 2000, The University of Chicago.

Lewis Carroll, Alice's Adventures in Wonderland 26 (Penguin Classics 1998). This passage describes the chaotic scene in which the Dodo and some other "curious creatures" demonstrated the Caucus-Race for the inquisitive Alice. The Race, apparently without rules or restrictions, involved the competitors running around in different directions, and it ended with uncertainty as to who was the winner.

29 USC $\$ 1001$ et seq (1994).

"Although the term "retirement" appears in the title of the law, ERISA covers a wider range of employee benefits than its name suggests. In addition to pension plans, ERISA also governs health care, disability, and accident benefit plans. See Barbara J. Coleman, Primer on Employee Retirement Income Security Act v (BNA 3d ed 1989).

Abuses included companies' failure to properly fund employee benefit plans or diversion of plan assets to other uses so that there was not enough money to pay benefits. See Dana J. Domone, Primer on ERISA Fiduciary Duties 1 (BNA 1994). See also HR Rep No 93-553, 93d Cong, 2d Sess 1 (1974), reprinted in 1974 USCCAN 4639 (stating that ERISA was intended "to remedy certain defects in the private retirement system").

"See Coleman, Primer on Employee Retirement Income Security Act at v (cited in note 3). 
establishing standards of conduct, responsibility, and obligation for fiduciaries of employee benefit plans, and by providing for appropriate remedies, sanctions, and ready access to the Federal courts."

As part of its remedies, ERISA provides for courts to award attorneys' fees to parties litigating employee benefit claims covered by the law. ' In the typical case, an ERISA beneficiary requests fee shifting as part of her recovery when she uses the court access provision of the statute to sue plan administrators to obtain denied benefits. ${ }^{8}$ Examples of such requests can be found in a wide variety of ERISA lawsuits, including claims for pension benefits' and employee health care coverage. ${ }^{10}$

Although any party can ask for and receive reimbursement for the costs of her legal efforts, courts have allowed fee shifting regularly only in certain categories of cases. The loose pattern of precedents in which courts either have enforced or rejected claims for attorneys' fees comprises the federal common law governing fee shifting under ERISA. These cases represent the federal courts' efforts to instill uniformity and order in their application of the otherwise open-ended statutory language of the ERISA fee shifting provision. Despite some progress toward coherence in the awarding of fees under ERISA, the absence of clear textual directives in the statute has led courts to reach conflicting outcomes, creating ambiguity as to when courts should require one party to pay another's legal expenses." For example, while success in a lawsuit is not explicitly required by the statutory language of ERISA, courts applying the statute have held that attorneys' fees should be awarded only to prevailing parties. Courts, thus, must face the unresolved problem of identifying parties properly eligible to receive attorneys' fees in ERISA litigation; that is, the courts must answer the question, "But who has won?"

This Comment explores the requirements that parties in ERISA litigation should have to meet in order for courts to properly grant

\footnotetext{
- 29 USC $\$ 1001$ (b).

29 USC \& $1132(\mathrm{~g})(1)$.

- See Ann C. Bertino, Comment, The Need for a Mandatory Award of Attorney's Fees for Prevailing Plaintiffs in ERISA Benefits Cases, 41 Cath U L Rev 871, 873-74 (1992) (outlining steps of an ERISA lawsuit).

- See Denzler v Questech, Inc, 80 F3d 97,99-100 (4th Cir 1996).

${ }^{10}$ See Tiemeyer v Community Mutual Insurance Co, 8 F3d 1094, 1095-97 (6th Cir 1993).

"See Cottrill v Sparrow, Johnson \& Ursillo, Inc, 100 F3d 220, 226 (1st Cir 1996) (acknowledging that the ERISA fee shifting doctrine presents "some conflicting authority"). See also Erik Phelps, Case Note, A Balancing Test for Attorney Fee Awards Under ERISA, 64 Geo Wash L Rev 846, 848 (1996) ("The result of this statutory grant of unbridled discretion is a split among the United States courts of appeals in the interpretation and application of the ERISA fee shifting provision."); David E. Gordon and Robert N. Eccles, ERISA Attorneys' Fees: An Unpredictable Situation, 6 Inside Litig 17 (Oct 1992) (commenting on the divergent practices of the courts in awarding ERISA attorneys' fees).
} 
their requests for fee shifting. More precisely, it considers possible ways for courts to determine whether the ERISA party asking for an award of attorneys' fees should receive such indemnification by virtue of winning at trial or obtaining a settlement. This Comment analyzes what it means to be a winner in ERISA litigation and proposes that courts focus on the legal merits of a party's case to determine if the party has prevailed.

Part I of this Comment considers the textual language and legislative history of the ERISA fee shifting provision. It then provides a broad overview of the case law that guides the courts in awarding attorneys' fees in ERISA cases. Part II narrows the scope of examination and specifically considers the different approaches that courts have taken to determine whether parties in ERISA lawsuits are eligible for fee shifting. Finally, Part III proposes a standard for evaluating whether ERISA litigants qualify as prevailing parties by considering the legal merits of the underlying claims. Part III also argues that courts should no longer use causation - the catalyst test-as the standard for defining when parties prevail in litigation. The use of the catalyst test for determining who has prevailed engenders doctrinal inconsistencies and undermines the efficiency of the ERISA litigation process. The proposed legal merits test offers a better solution to the prevailing party dilemma. Specifically, it has two advantages over the causation analysis that many courts now use. First, the legal merits test allows ERISA's definition of prevailing party to make more sense in the context of other rules associated with ERISA fee shifting. Second, the proposed standard promotes efficiency in ERISA litigation, by encouraging parties to pursue efficient, welfare-enhancing settlements and allowing courts to conserve judicial resources.

\section{OVERVIEW OF THE EXISTING PRACTICE OF FEE SHIFTING UNDER ERISA}

\section{A. Statutory Authority for Fee Shifting in ERISA}

As a general rule, parties are not entitled to recover the costs of their legal efforts from their opponents. ${ }^{12}$ However, statutory provisions may give courts the authority to award attorneys' fees in certain kinds of litigation. ${ }^{13}$ The fee shifting provision in ERISA gives courts

12 See David Shub, Note, Private Attorneys General, Prevailing Parties, and Public Benefit: Attorney's Fees Awards for Civil Rights Plaintiffs, 42 Duke L J 706, 709 (1992) (stating that the American rule requires each party in a civil case to bear its own attorneys' fees); Thomas $D$. Rowe, Jr., The Legal Theory of Attorney Fee Shifting: A Critical Overview, 1982 Duke L J 651 (describing the general American practice of making each party responsible for the costs of its legal actions).

"See Rowe, 1982 Duke L J at 651 (cited in note 12) (explaining that statutory provisions for fee shifting can allow departures from the usual prohibition against the awarding of attorneys' 
the discretion to require one party to indemnify the other party's legal expenses. ${ }^{14}$

The statutory language through which ERISA grants courts the power to award attorneys' fees is broad and unconstrained: "[T]he court in its discretion may allow a reasonable attorney's fee and costs of action to either party." limits to the courts' discretion in awarding attorneys' fees. Legislative history is equally unhelpful in suggesting proper applications of fee shifting under ERISA. ${ }^{16}$ With no other guidance available, ERISA seems to authorize the courts to exercise unbridled discretion in fee shifting. ${ }^{17}$

Responding to the absence of instructions on how to apply the ERISA fee shifting provision, courts have developed a set of rules to limit their own discretion in the awarding of attorneys' fees. ${ }^{18}$ These rules control the process through which courts decide whether to grant petitions for fees. ${ }^{19}$ Although some differences exist, courts generally proceed along a two-step process to determine whether fee shifting is appropriate: first, they ask whether the fee applicant is a prevailing party eligible to receive attorneys' fees, ${ }^{20}$ and second, they consider whether the case presents the proper conditions for fee shifting.

\section{B. Proper Conditions for Fee Shifting}

The Tenth Circuit was the first circuit to establish a standard for determining the appropriateness of awarding ERISA attorneys' fees

fees).

See Eaves $v$ Penn, 587 F2d 453, 464-65 (10th Cir 1978) (commenting that $\S 1132(\mathrm{~g})(1)$ of ERISA allows courts to award attorneys' fees).

15 29 USC $\$ 1132(\mathrm{~g})(1)$.

"See Armistead v Vernitron Corp, 944 F2d 1287, 1303 (6th Cir 1991) ("[N]o history exists to provide guidance to the courts.").

${ }_{17}$ See Eddy v Colonial Life Insurance Co of America, 59 F3d 201, 203 (DC Cir 1995) ("Neither the statute nor the legislative history indicates whether or how that discretion should be guided."). See also Phelps, 64 Geo Wash L Rev at 848 (cited in note 11) (noting the absence of guidance for courts in the application of the ERISA fee shifting provision).

${ }^{*}$ See Hummell v S.E. Rykoff \& Co, 634 F2d 446, 453 (9th Cir 1980) (agreeing with other circuits that courts should have guidelines to limit their discretion to apply ERISA's fee shifting provision); Eaves, $587 \mathrm{~F} 2 \mathrm{~d}$ at 465 (prescribing factors for courts to consider when they are determining whether to award attorneys' fees).

"For a basic description of the ERISA fee shifting process, see Mark Howard Berlind, Note, Attorney's Fees Under ERISA: When is an Award Appropriate?, 71 Cornell L Rev 1037, 1038-49 (1986).

${ }^{2}$ See, for example, Martin v Blue Cross \& Blue Shield of Virginia, Inc, 115 F3d 1201, 1210 (4th Cir 1997) (holding that only prevailing parties can be eligible for further fee shifting considerations), cert denied, 522 US 2029 (1997); Flanagan v Inland Empire Electric Workers Pension Plan and Trust, 3 F3d 1246, 1253 (9th Cir 1993) (concluding that attorneys' fees may not be awarded to parties who have not succeeded in litigation). 
in Eaves $v$ Penn. ${ }^{21}$ The Eaves court held that courts should balance five factors in any decision to award ERISA attorneys' fees. ${ }^{2}$ These factors are:

(1) the degree of the offending parties' culpability or bad faith; (2) the degree of the ability of the offending parties to personally satisfy an award of attorneys fees; (3) whether or not an award of attorneys fees against the offending parties would deter other persons acting under similar circumstances; (4) the amount of benefit conferred on members of the pension plan as a whole; and (5) the relative merits of the parties' position [s]. ${ }^{23}$

This five-part test quickly gained widespread acceptance among the different federal circuits, and courts most commonly apply this test to determine the propriety of awarding attorneys' fees in ERISA lawsuits. ${ }^{24}$

The Eaves test is a product of the courts' interpretation of ERISA and is not statutorily required in any sense. As such, it is not the exclusive test used by the courts to determine the appropriateness of fee shifting. ${ }^{25}$ However, despite the criticism that the Eaves factors are judicial constructions lacking a basis in law, the Eaves test is still the most commonly accepted standard that courts apply when awarding attorneys' fees under ERISA. ${ }^{27}$

${ }^{2 n} 587$ F2d 453, 464-65 (10th Cir 1978).

Id.

Id at 465 .

" Every circuit has applied the Eaves five-part test in some form or another. Even circuits that developed their own ERISA fee shifting standards have occasionally turned to the factors found in Eaves. See Gray v New England Telephone \& Telegraph Co, 792 F2d 251, 257-58 (1st Cir 1986); International Brotherhood of Teamsters $v$ New York State Teamsters Council Health \& Hospital Fund, 903 F2d 919, 923-24 (2d Cir 1990); Ellison v Shenango Inc Pension Board, 956 F2d 1268, 1273 (3d Cir 1992); Quesinberry v Life Insurance Co of North America, 987 F2d 1017, 1028-29 (4th Cir 1993) (en banc); Iron Workers Local No $272 v$ Bowen, 624 F2d 1255, 1266 (5th Cir 1980); Tiemeyer v Community Mutual Insurance Co, 8 F3d 1094, 1101 (6th Cir 1993); Leigh v Engle, 858 F2d 361, 369-70 (7th Cir 1988); Lawrence $v$ Westerhaus, 749 F2d 494, 495-96 (8th Cir 1984); Hummell v S.E. Rykoff \& Co, 634 F2d 446, 453 (9th Cir 1980); Nachwalter v Christie, 805 F2d 956, 961-62 (11th Cir 1986); Eddy v Colonial Life Insurance Co of America, 59 F3d 201, 206 (DC Cir 1995).

"See Hummell, $634 \mathrm{~F} 2 \mathrm{~d}$ at 453 (directing district courts to consider the Eaves factors "among others" for awarding ERISA attorneys' fees); Iron Workers, $624 \mathrm{~F} 2 \mathrm{~d}$ at 1266 (noting that none of the Eaves "factors is necessarily decisive, and some may not be apropos in a given case"); Cottrill v Sparrow, Johnson \& Ursillo, Inc, 100 F3d 220,225 (1st Cir 1996) (finding that the Eaves factors "are exemplary rather than exclusive").

"See Armistead v Vernitron Corp, 944 F2d 1287, 1303 (6th Cir 1991) ("The Eaves court has been criticized for failing to explain how it developed the factors or why they should be used.").

"See id at 1303-04 (commenting that the "broad wording of the statute has the effect of ... permitting the federal courts to devise a common law of fee-shifting" and that the Eaves factors "are as good a place as any to begin the development of a common law of fee-shifting under ERISA, even if they do not turn out to be the final word on the subject"). 
An alternative to the Eaves standard is a two-part test created by the Seventh Circuit in Bittner $v$ Sadoff \& Rudoy Industries. ${ }^{28}$ Under the Bittner test, courts should award attorneys' fees to winning parties in ERISA litigation unless (1) the losing parties have argued a position with a solid basis that was more than merely not frivolous, but less than meritorious, or (2) special circumstances have made awarding fees unjust. ${ }^{29}$ While some courts have chosen to apply the Bittner twopart test to determine whether awards of attorneys' fees were justified, ${ }^{30}$ it is unclear whether this test adds anything to the ERISA fee shifting doctrine. The Bittner court itself stated that its decision did not question "the soundness or utility" of the Eaves factors. "Other courts also have observed that the different tests should always lead to the same results because they ask the same basic questions. Sentiment of this kind demonstrates, on the whole, the cohesiveness of the courts on how they should determine the propriety of fee shifting.

\section{Presumptions for Fee Shifting}

Notwithstanding the general agreement on what factors should guide ERISA fee shifting, courts sometimes disagree on how freely they should award attorneys' fees. Most courts have favored a neutral approach to fee shifting in ERISA litigation-that is, they have no presumption in favor or against it. ${ }^{33}$ However, a small number of

728 F2d 820 (7th Cir 1984).

Id at 830 .

s See Holder v Prudential Insurance Co of America, 951 F2d 89, 91-92 (5th Cir 1992) (finding denial of fees proper even under Bittner); Tesch v General Motors Corp, 937 F2d 359, 362 (7th Cir 1991) (reversing award of attorneys' fees using Bittner); Nichol v Pullman Standard, Inc, 889 F2d 115, 121-22 (7th Cir 1989) (affirming district court's use of Bittner in denying fees); Sigmon Fuel Co v Tennessee Valley Authority, 754 F2d 162,166 (6th Cir 1985) (applying Bittner). But see Ellison, 956 F2d at 1274 (rejecting the plaintiff's "request to adopt the special circumstances rule"); $E d d y, 59 \mathrm{~F} 3 \mathrm{~d}$ at $206 \mathrm{n} 8$ (stating that the Bittner test's rationale was unpersuasive).

"Bittner, 728 F2d at 829.

"Little v Cox's Supermarkets, 71 F3d 637, 644 (7th Cir 1995) ("[W]hichever approach is used, the 'bottom-line question' is the same."). See also Tesch, 937 F2d at 363 ("We need not concern ourselves with choosing between the multi-factor approach and Bittner's 'substantially justified' standard. It is difficult to imagine a situation in which the application of one model rather than the other would alter our decision concerning the propriety of an award of costs or fees.").

"See Denzler v Questech, Inc, 80 F3d 97,104 (4th Cir 1996) (stating that "there was no presumption in favor of awarding attorney's fees to a prevailing insured or beneficiary"); Eddy $v$ Colonial Life Insurance Co of America, 59 F3d 201, 204 (DC Cir 1995) ("Although we agree that ERISA lawsuits vindicate important interests, we are unpersuaded that these interests justify the presumptive award of fees."); McPherson $v$ Employees' Pension Plan of American Re-Insurance Co, Inc, 33 F3d 253, 254 (3d Cir 1994) ("We have further instructed that there is no presumption that a successful plaintiff in an ERISA suit should receive an award in the absence of exceptional circumstances"); Ellison v Shenango Inc Pension Board, 956 F2d 1268, 1275 (3d Cir 1992) ("We do not think a presumption in favor of granting attorney's fees to prevailing plaintiffs is required or appropriate."); Armistead v Vernitron Corp, 944 F2d 1287, 1303 (6th Cir 1991) (re- 
courts have argued that there should be a presumption for awarding attorneys' fees to ERISA plaintiffs. ${ }^{34}$

Supporters of a fee shifting presumption have compared ERISA to federal civil rights statutes, ${ }^{35}$ and have contended that the similar remedial nature of ERISA to civil rights laws justifies the presumption that plaintiffs "should ordinarily receive attorney's fees." ${ }^{, 36}$ Opponents of the fee shifting presumption have rejected this reasoning and have pointed out that the analogy between ERISA and statutes protecting civil rights is inapt because ERISA concerns a matter of less public importance ${ }^{37}$ and because ERISA litigants have sufficient private pecuniary motives to sue for their own rights.

It is questionable whether the presence of a presumption for fee shifting in ERISA litigation really changes how courts actually award

fusing "to treat all successful ERISA plaintiffs as private attorneys general" entitled to fees); Iron Workers Local No 272 v Bowen, 624 F2d 1255, 1265-66 (5th Cir 1980) (rejecting argument that attorneys' fees should be awarded to plaintiffs as a matter of course).

" See, for example, Stanton v Larry Fowler Trucking, Inc, 52 F3d 723, 729 (8th Cir 1995) (declaring that a prevailing ERISA plaintiff should ordinarily receive awards of attorneys' fees); Hechenberger $v$ Western Electric Co, Inc, 786 F2d 347, 348 (8th Cir 1986) (stating a presumption for fee shifting in ERISA litigation).

"See Landro v Glendenning Motorways, Inc, 625 F2d 1344, 1356 (8th Cir 1980) (comparing ERISA to other federal remedial legislation that allows attorneys' fees awards, such as the Civil Rights Act of 1964, 42 USC $\$ 2000 \mathrm{a}-3$ (b) (1994), and the Civil Rights Attorney's Fees Award Act of 1976, 42 USC $\$ 1988$ (b) (1994)).

smith v CMTA-IAM Pension Trust, 746 F2d 587,590 (9th Cir 1984).

"See Eddy, 59 F3d at 205-06 ("We join those circuits which have concluded that the special reasons for adopting a fee-shifting presumption in civil rights actions do not warrant adopting the presumption in ERISA cases."); Armistead, $944 \mathrm{~F} 2 \mathrm{~d}$ at 1303 ("Because this litigation so patently lacks the public importance of a civil rights suit, it is an apt illustration of our reasons for refusing ... to treat all successful ERISA plaintiffs as private attorneys general, absent some special circumstance."); Iron Workers, $624 \mathrm{~F} 2 \mathrm{~d}$ at 1265 ("The policies underlying ERISA are certainly important ones, but they simply do not rise to the level of assuring that all citizens are accorded their civil rights.").

"See Eddy, 59 F3d at 206 ("Neither ERISA's language nor its legislative history imply the presumption, and fee-shifting is less necessary as an incentive in ERISA, not because ERISA protects unimportant interests, but because the interests it protects are monetary, rather than dignitary.").

In contrast, a presumption for fee shifting exists under antitrust law even though the plaintiffs in those cases frequently have significant private pecuniary motives. See Premier Electrical Construction Co v National Electrical Contractors Association, Inc, 814 F2d 358, 373 (7th Cir 1987) (noting that antitrust law provides for fee shifting); Home Placement Service, Inc v Providence Journal Co, 819 F2d 1199, 1210 (1st Cir 1987) (characterizing fee shifting under antitrust law as "mandatory"); Baughman v Cooper-Jarrett, Inc, 530 F2d 529, 531 n 2 (3d Cir 1976) (arguing that courts should typically award attorneys' fees in antitrust litigation). The analogy between ERISA and antitrust law may be inapt, however, because fee shifting under antitrust law involves a completely different set of considerations than ERISA fee shifting. For example, unlike ERISA fee shifting, courts awarding attorneys' fees in antitrust cases have not established a prevailing party requirement. See Gulfstream III Associates, Inc v Gulfstream Aerospace Corp, 995 F2d 414, 418 (3d Cir 1993) ("There is no 'prevailing party' language in Section 4 of the Clayton Act."); United States Football League v National Football League, 704 F Supp 474, 479-80 (S D NY 1989) (commenting that even the plaintiff who has won only nominal damages can still recover attorneys' fees in antitrust litigation). 
attorneys' fees. Most courts have been inconsistent and have applied a presumption in some cases but not others. ${ }^{39}$ Another reason to think that a presumption does not affect the final analysis of the courts much is that most courts use the Eaves test for fee shifting. ${ }^{40}$ Finally, the courts are uniform in granting only the requests of prevailing parties for attorneys' fees regardless of whether a presumption exists." These reasons all suggest that the fee shifting presumption has little influence over the awarding of attorneys' fees in ERISA cases.

\section{The PREVAILING PARTY PROBLEM}

\section{A. The Prevailing Party Requirement}

Although courts generally follow the Eaves factors in assessing whether fee shifting is proper, they have achieved less uniformity in resolving the question of who is eligible to receive attorneys' fees. The language of ERISA clearly allows the possibility of awarding attorneys' fees to any party. ${ }^{42}$ This means that the law provides anyonewinning plaintiffs, winning defendants, losing plaintiffs, or losing defendants - a chance to successfully recover the costs of ERISA actions. ${ }^{43}$

However, ERISA fee shifting is much different in practice. Courts consistently have resisted the idea of awarding attorneys' fees to losing parties in ERISA lawsuits, and courts have only rarely permitted fee shifting for parties who had not yet won. ${ }^{44}$ Indeed, the standard

30 Compare Chambless $v$ Masters, Mates \& Pilots Pension Plan, 815 F2d 869, 872 (2d Cir 1987) (urging that that "attorney's fee provisions must be liberally construed to protect the statutory purpose of vindicating retirement rights, even when small amounts are involved"), with International Brotherhood of Teamsters $v$ New York State Teamster Council Health \& Hospital Fund, 903 F2d 919, 923-24 (2d Cir 1990) (requiring the district court to apply the Eaves factors after stating that ERISA did not require "mandatory" fee shifting). And compare Nachwalter $v$ Christie, 805 F2d 956, 962 (11th Cir 1986) (admonishing courts to remember the "essential remedial purpose" of ERISA to protect beneficiaries of pension plans), with McKnight $v$ Southern Life \& Health Insurance Co, 758 F2d 1566, 1572 (11th Cir 1985) (rejecting the plaintiff's demand for attorneys' fees and cautioning courts to refrain from awarding attorneys' fees to prevailing parties outright).

¿ See note 24.

"See, for example, Flanagan $v$ Inland Empire Electric Workers Pension Plan \& Trust, 3 F3d 1246,1253 (9th Cir 1993) ("[W] nonetheless conclude that a fee award is inappropriate now because they have not established a right to benefits, nor shown that the Plan or its fiduciaries have violated ERISA."); Lawrence v Westerhaus, 749 F2d 494, 496 (8th Cir 1984) ("[A] court may properly deny a claim for attorneys' fees solely on the ground that the plaintiff obtained no relief under the statute.").

" The language of ERISA allows courts to exercise their discretion in awarding attorneys' fees to "either" party. See 29 USC § 1132(g)(1).

- See Berlind, 71 Cornell L Rev at 1038 (cited in note 19) (discussing all four classes of litigants while noting that no court would ever allow losing defendants to recover fees).

" See Phelps v US West, Inc,1998 US App LEXIS 6667, *7 (10th Cir) ("Although the statute is not express on this point, most courts, including this one, have interpreted ERISA to allow an award of attorney's fees only to prevailing parties."); Martin $v$ Blue Cross \& Blue Shield of Virginia, Inc, 115 F3d 1201, 1210 (4th Cir 1997) ("[W]e have often indicated that reversal of a judg- 
courts apply to determine whether fee shifting is appropriate seems to assume implicitly that only winning parties are eligible to recover attorneys' fees. For example, courts applying the Eaves five-part test must look to certain factors-such as whether awarding attorneys' fees would satisfy a deterrence purpose ${ }^{45}$ or whether the parties' positions have unequal merit ${ }^{46}$-that can make sense only if the attorneys' fees are to be awarded to prevailing parties." Likewise, the Bittner court did not imagine that its two-part test would be applied to losing parties. ${ }^{48}$

Although courts have awarded attorneys' fees to prevailing plaintiffs and defendants in past cases, it is clear that the application of the ERISA fee shifting doctrine favors the former far more than the latter. Many circuits have expressed the view that courts ordinarily should not award ERISA attorneys' fees to prevailing defendants. The use of the Eaves test strengthens this presumption against requiring ERISA plaintiffs to pay attorneys' fee awards because many of the Eaves factors seem more applicable to plaintiffs than defendants. ${ }^{\text {so }}$ Nonetheless, courts in some instances have ordered plaintiffs

ment under ERISA also requires reversal of any attendant award of attorneys' fees. ... Moreover, many of our sister circuits have imposed a 'prevailing party' limitation on the availability of attomeys' fees under ERISA.... [O]nly a prevailing party is entitled to consideration for attorneys' fees in an ERISA action."), cert denied, 522 US 1029 (1997); Flanagan v Inland Empire Electric Workers Pension Plan \& Trust, 3 F3d 1246, 1253 (9th Cir 1993) (holding that plaintiff must succeed on a "significant issue of litigation" to merit an award of attorneys' fees). But see Miller v United Welfare Fund, 72 F3d 1066, 1074 (2d Cir 1995) (noting that ERISA "contains no requirement that the party awarded attorneys' fees be the prevailing party"). See also Kayes $v$ Pacific Lumber Co, 51 F3d 1449, 1469 (9th Cir 1995) (holding interim attorneys' fees available to plaintiff even though the ERISA litigation had not yet reached its conclusion and the plaintiff had not prevailed on a final judgment).

"See Eddy v Colonial Life Insurance Co of America, 59 F3d 201, 208 (DC Cir 1995) ("[T]he deterrent purpose of awarding attorneys' fees extends not only to deterring violations of ERISA but also to deterring unnecessary prolongation or unjust resolution of ERISA claims."); Little v Cox's Supermarkets, 71 F3d 637, 644-45 (7th Cir 1995) (awarding attorneys' fees against a losing party who presented a case with absolutely no merit).

See Denzler v Questech, Inc, 80 F3d 97, 104 (4th Cir 1996) (concluding that the "relative merits of the parties' positions weighs in favor of awarding fees").

- Other Eaves factors also suggest that only prevailing parties are entitled to receive attorneys' fees. See, for example, Ellison $v$ Shenango Inc Pension Board, 956 F2d 1268, 1275 (3d Cir 1992) (concluding that courts can allow fee shifting on the basis of the "offending" party's "culpability or bad faith").

"See Bittner v Sadoff \& Rudoy Industries, 728 F2d 820, 829 (7th Cir 1984) ("[I]t would be an abuse of discretion for the district court to award attorney's fees to a losing party.").

"See Flanagan, 3 F3d at 1253 ("We reject the defendant's fee request because we see no justification, on this record, to displace our common perception that attorney's fees should not be charged against ERISA plaintiffs."); Nachwalter v Christie, 805 F2d 956, 962 (11th Cir 1986) (explaining that courts should refrain from "charging fees against ERISA beneficiaries since private actions by beneficiaries seeking in good faith to secure their rights under employee benefit plans are important mechanisms for furthering ERISA's remedial purpose").

see Gray v New England Telephone and Telegraph Co, 792 F2d 251, 259 (1st Cir 1986) ("Factors may simply not weigh equally where defendants rather than plaintiffs seek fees."). See 
to pay the defendants' attorneys' fees in cases where the plaintiffs' claims clearly lacked substance or were abusive.

\section{B. Definitions for Prevailing Party}

While the idea that only prevailing parties should receive ERISA attorneys' fees is widely accepted, it is still unclear what it means for a party to have prevailed. In other words, to what extent must a party win its case in order to be considered prevailing? In some situations, this question can be extremely difficult. If parties to an ERISA action settle the case before trial, which party, if any, is the prevailing party? Other situations, such as the completion of a trial with a verdict, are normally easier to resolve. Even then, however, courts still must determine whether a party has won enough from the verdict to be considered prevailing. Must a prevailing party win all of its claims or just a substantial portion? Is it enough for a party to win only one of its principal claims? Some courts have addressed these problems, but there is no established or consistent standard for determining the prevailing party in ERISA litigation. ${ }^{53}$

also Berlind, 71 Cornell L Rev at 1046 (cited in note 19) (finding that Eaves factors "can rarely be used to assess fees against a losing plaintiff"). However, the Bittner test is neutral between plaintiffs and defendants. See Bittner, 728 F2d at 829 ("ERISA does not create a presumption in favor of a prevailing plaintiff's request for fees and against a prevailing defendant's.").

${ }^{s t}$ See Little, 71 F3d at 644-45 (awarding attorneys' fees to the defendant because the plaintiff produced no evidence backing her claims and established no genuine issue of material fact "despite considerable discovery"); Operating Engineers Pension Trust v Gilliam, 737 F2d 1501, 1506 (9th Cir 1984) (granting the defendant's request for attorneys' fees because "the prosecution of this suit was grossly unfair"). The main reason why courts have allowed defendants to recover attomeys' fees in some ERISA cases is because they wanted to discourage plaintiffs from initiating frivolous lawsuits in bad faith. On the other hand, courts have also wanted to be careful not to punish plaintiffs too harshly for starting lawsuits that seemed reasonable at the beginning, but failed for whatever reason. See Berlind, 71 Cornell L Rev at 1046 (cited in note 19).

s2 The complexities of winning and losing in litigation can make it extremely difficult to identify prevailing parties. Consider the following view:

Many fee-shifting cases do not involve simple two-party, single-issue lawsuits. Plaintiffs may win some but not all of their substantive claims, receive some but not all of the remedy sought, or attain some but not all of their collateral aims. When they do realize their goals, it may not be by verdict and judgment, but by settlement or by legislative or administrative action. Determining whether a plaintiff is a prevailing party for fee-shifting purposes is often difficult.

Dan B. Dobbs, Awarding Attorney Fees Against Adversaries: Introducing the Problem, 1986 Duke L J 435, 449-50.

In addition to the two standards discussed in this Comment, a small number of courts have applied independent standards to determine whether the party requesting fee shifting was a qualified prevailing party. One court allowed fee shifting even though the party receiving the attorneys' fees lost some of its arguments on appeal, because the party had won enough benefits before the appeal to be considered a prevailing party. See Sokol v Bernstein, 812 F2d 559, 561 (9th $\mathrm{Cir}$ 1987). In cases where the litigants seeking fees won some of their claims, courts have identified the parties as only partially prevailing and have awarded reduced attorneys' fees accordingly. See Downey Community Hospital v Wilson, 977 F2d 470, 474 (9th Cir 1992) (refusing 
1. The Hooper test.

Federal courts have proposed different tests to identify which ERISA litigants are prevailing parties. The Seventh Circuit proposed one solution in Hooper $v$ Demco, Inc $c^{\text {s4 }}$ that has received some support from other courts. In Hooper, a cancer patient sued his former employer after he was denied coverage under the employee health plan for the costs of a controversial chemotherapy treatment. ${ }^{36}$ Shortly after the lawsuit was filed, the parties entered into a settlement agreement in which the defendant helped the plaintiff find money for the treatment from other sources." The plaintiff sought recovery of attorneys' fees on the basis that he effectively had "won" the benefits he sought."

Noting that ERISA attorneys' fees ordinarily should be awarded only to prevailing parties, the Hooper court first observed that not every settlement situation will produce a prevailing party because litigants sometimes settle for reasons unrelated to the substance and issues of a case. ${ }^{59}$ Consequently, parties in ERISA lawsuits must satisfy two conditions to prove that they have prevailed. First, a litigant must prove that her lawsuit was a material factor in obtaining relief. ${ }^{60} \mathrm{Sec}-$ ond, a litigant must demonstrate that she accomplished the goals of her lawsuit on the strength of the merits of her case. ${ }^{61}$ Applying these conditions to the case in Hooper, the court found that the plaintiff was not a prevailing party because he never presented a credible case and received relief only due to the charitable acts of the defendant.

to award attorneys' fees for costs associated with parts of lawsuit that did not result in ERISA benefits); Cefali v Buffalo Brass Co, Inc, 748 F Supp 1011, 1019 (W D NY 1990) (reducing amount of fee shifting because the "plaintiffs achieved only partial success at best"). The alternative tests introduced by these cases represent unusual departures from the mainstream jurisprudence of ERISA fee shifting. For the most part, courts do not follow these rules. Accordingly, the discussion here does not require more than a comparison between the legal merits test and the catalyst test-the two central standards that courts most often choose between when deciding whether to award attorneys' fees under ERISA.

37 F3d 287 (7th Cir 1994).

"See Phelps v US West, Inc, 1998 US App LEXIS 6667, *8-10 (10th Cir) (applying Hooper to determine the prevailing party in a health benefits case); Davis v Wal-Mart Stores, Inc, 1999 US Dist LEXIS 15281, *31-36 (D Kan) (same).

See Hooper, 37 F3d at 288-90.

Id at $290-91$.

Id at 291.

"Id at 292 ("A suit may be groundless, and settled for its nuisance value, or settled by a party for wholly gratuitous reasons, thus not justifying an award of attorney's fees.").

Id.

"Id at 293.

"3 The Hooper court specifically pointed out that the evidence overwhelmingly vindicated the defendant's refusal to pay for the costs of the "experimental" and "investigative" treatment. The court also praised the defendant's efforts to secure help for the plaintiff outside of the health plan coverage. Id at 294 ("Further, gratuitous donations to aid a dying person cannot and does [sic] not rise to the level of satisfying the standard of prevailing party in an ERISA lawsuit."). 
2. The catalyst test.

Other courts have come up with different approaches to determining whether a party has prevailed in ERISA litigation. Some have applied a simple catalyst test, asking whether the litigant's victory was caused by her efforts in the lawsuit. ${ }^{63}$ This means that there must be some sort of causal relationship between the relief obtained and the litigation. ${ }^{s}$ Typically, litigants have satisfied the catalyst test if they were better off after the ERISA lawsuit than they were before. ${ }^{65}$ The threshold for showing gains from litigation is low, and courts have considered parties to have prevailed even where the litigant gained no actual benefits and instead won only the right to see certain documents about a retirement plan ${ }^{66}$ or the right to be notified about reasons for the denial of benefits. The threshold for establishing causa-

"For background and a description of the catalyst test, see Joel $\mathrm{H}$. Trotter, Note, The Catalyst Theory of Civil Rights Fee Shifting After Farrar v. Hobby, 80 Va L Rev 1429, 1433-37 (1994). See also Laura E. Flenniken, No More Plain Meaning: Farrar v. Hobby, 71 Denver U L Rev 477, 479 \& n 12 (1994) (explaining the catalyst test). In a sense, the catalyst test is synonymous with a "but for" test of causation. See Milton v Shalala, 17 F3d 812, 813-14 (5th Cir 1994) (describing a case in which "a claimant's law suit was a necessary cause of the favorable redetermination of the claimant's rights, providing a catalyst for the restoration of benefits ... [and as a result] the court found a sufficient link between the litigation and the restoration of benefits to justify characterizing the claimant as a party succeeding in litigation" and stating that "[t]his rationale has also been called the 'but for' causation theory"). Under this test, a party can become a prevailing party even by obtaining relief outside of litigation. See id at 814-15 ("This theory recognizes that though a claimant may not succeed in court if a settlement or remedial action renders the law suit moot, he may nonetheless be considered a prevailing party if his law suit was a catalyst in attaining remedial action."). See also Walling v Brady, 1997 US Dist LEXIS 17205, *3 n 2 (D Del) ("[W] hen a plaintiff 'obtains some of the benefit sought through a settlement she is a prevailing party and will be entitled to a fee award unless the court finds it to be an exceptional case.").

See McManus v Gitano Group, Inc, 59 F3d 382, 384 (2d Cir 1995) ("Recovery of fees on a catalyst theory requires an applicant to demonstrate a causal connection between the litigation and the recovery of benefits."); Cefali v Buffalo Brass Co, Inc, 748 F Supp 1011, 1017-18 (W D NY 1990) (finding that a causal connection between the relief obtained and the litigation in which the fees are sought exists if the suit was a catalytic factor in attaining the relief); Petro $v$ Flintkote Co,633 F Supp 10,11 (N D Ohio 1986) ("[A] plaintiff may qualify as a prevailing party if the lawsuit is casually [sic] related to securing the relief obtained.").

"See Algie v RCA Global Communications, Inc, 891 F Supp 870, 890 (S D NY 1994) (recognizing the plaintiff as the prevailing party for winning a single claim out of six), affd, 60 F3d 956 (2d Cir 1995); Cefali, 748 F Supp at 1018 (awarding attorneys' fees to the plaintiff who had recovered some benefits through settlement); Petro,633 F Supp at 11 ("Plaintiffs achieved some of the benefit in bringing their ERISA claim, and are therefore entitled to reasonable attorneys' fees under 29 USC $\$ 1132(\mathrm{~g})$."). Sometimes, courts also apply the catalyst test without expressly indicating that they are doing so. See O'Rourke $v$ Pitney Bowes, Inc, 1997 US Dist LEXIS 17929, *9-10 (S D NY) (recognizing plaintiff as prevailing party because the lawsuit brought about some of the benefits sought).

see Groves $v$ Modified Retirement Plan for Hourly Paid Employees of Johns Manville Corp, 803 F2d 109, 119 (3d Cir 1986).

${ }^{67}$ See Christian v Dupont-Waynesboro Health Care Coverage Plan, 12 F Supp 2d 535, 537-38 (W D Va 1998). 
tion is also easy to meet, and plaintiffs have satisfied the catalyst test in some cases by the simple fact that they filed a lawsuit. ${ }^{68}$

\section{ADOPTING A MORE SENSIBLE STANDARD: IDENTIFYING PREVAILING PARTIES THROUGH CONSIDERATIONS OF LEGAL MERITS}

This Part argues that the federal courts should abandon the catalyst test as a means for defining the prevailing party under ERISA fee shifting. Instead, they should embrace the premise of the Hooper test - that the substance of what a party argues in litigation is relevant to whether it becomes eligible to receive attorneys' fees-and craft a legal rule that considers legal merits in the prevailing party determination. The legal merits test has both doctrinal and policy advantages over the catalyst test. Doctrinally, the legal merits test allows the definition of prevailing party to comport with other rules of ERISA fee shifting and creates a better fit for ERISA fee shifting in the universe of fee shifting provisions under federal law. From a policy perspective, the legal merits test better promotes efficiency in the ERISA litigation process than the catalyst test. By holding parties to a higher standard, the legal merits test correspondingly creates incentives for parties to seek welfare-enhancing settlements and allows courts to save valuable judicial resources.

\section{A. A Proposal for the Legal Merits Test}

The federal courts should reject the catalyst test and look at the merits of the case presented by the party requesting attorneys' fees. Under the proposed legal merits test, a party that succeeds with a strong and persuasive ERISA claim would qualify as a prevailing party whereas a party with a dubious claim would not. To make this determination, courts should look to strengths of the arguments advanced by the party seeking attorneys' fees. For example, courts can take into account whether a party has exposed the error of her opponent, ${ }^{69}$ or whether a party has proved the validity of her claims. ${ }^{70}$ The legal merits test argues for eschewing the precept of the catalyst test-

\footnotetext{
See Hamilton v Bank of New York (Delaware), 1995 US Dist LEXIS 10464, *12-13 (D Del) ("[T] he filing of suit appears to have precipitated defendants' reversal of eligibility determination for plaintiff, which also indicates that plaintiff has prevailed.").

See Perlman v Swiss Bank Corp Comprehensive Disability Protection Plan, 990 F Supp 1039,1041 (N D Ill 1998) (ruling that the plaintiff prevailed because she convinced the court that the defendant wrongfully denied her ERISA benefits).

"See Painter y Golden Rule Insurance Co, 121 F3d 436, 441 (8th Cir 1997) (denying prevailing party status to the plaintiff because she did not prove the validity of her claims and won only on procedural grounds).
} 
that winning anything is sufficient to establish a party as prevailing." Courts should instead distinguish between parties that win based on the merits of their case and parties that win due to technicalities. Essentially, the legal merits test moves courts away from a purely technical understanding of what it means to "come out ahead" from a lawsuit, and instead has courts consider honestly whether the party seeking attorneys' fees actually deserves them."

In a sense, some courts already take into account legal merits when they decide prevailing party questions, although they do so with varying degrees of explicitness. In Hooper $v$ Demco, Inc, ${ }^{73}$ the court considered the strength of the plaintiff's case when it held that the plaintiff did not satisfy the prevailing party requirement because the defendant had settled the case gratuitously. ${ }^{74}$ Other courts have used the same sort of evaluation in the non-settlement context. ${ }^{75}$ In Perlman v Swiss Bank Corp Comprehensive Disability Protection Plan, the court, after concluding that the plaintiff had succeeded on one of her claims, held that the plaintiff met the requirements to be a prevailing party by showing that the defendant had violated ERISA. ${ }^{n}$ In contrast, the court in Quinn $v$ Blue Cross and Blue Shield Corp ${ }^{78}$ declined to treat the plaintiff as a prevailing party, even though she had technically won her case, because she failed to demonstrate convincingly that the defendant acted without justification. ${ }^{79}$

"See notes 66-68 and accompanying text.

"Although it may seem that this standard invites courts to impose their own sense of desert, it actually does not. The development of precedents for what constitutes meritorious claims will certainly constrain courts to a degree. Indeed, by making the merits determination explicit, the proposed test should establish rules that limit discretion much in the same way as the Eaves factors. See note 18 and accompanying text.

37 F3d 287.

" Id at 293. See also Sullivan v Gavin, 1995 US Dist LEXIS 3981, *7-8 (N D Ill) (applying the Hooper test to deny a plaintiff status as a prevailing party because it was not the merits of the plaintiff's case that led the defendant to act); Davis $v$ Wal-Mart Stores, Inc, 1999 US Dist LEXIS 15281, *35 (D Kan) ("However, she has not shown that the Plan paid her benefits based solely on the strength of her case.").

"See Painter $v$ Golden Rule Insurance Co, 121 F3d at 441 (stating that the plaintiff was not a prevailing party because she only won in the sense that the defendant admitted a procedural error in its declaratory judgment motion); First National Bank of Chicago $v$ Retirement Trust for Employees of the Standard Oil Co and Subsidiaries, 1992 US Dist LEXIS 5662, *5 (N D IIl) ("Prevailing parties are usually those who succeed on the substantive merits and not merely on procedural claims."). See also Spellman v Aetna Plywood, Inc, 1991 US Dist LEXIS 6489, *9 (N D Ill) (declining to award attorneys' fees because neither party successfully proved the other party's case "unmeritorious").

990 F Supp 1039 (N D Ill 1998).

" Id at 1041 ("I find that Ms. Perlman is a prevailing party. Ms. Perlman filed suit seeking to overturn the denial of her disability benefits. I found that UNUM's denial of benefits was arbitrary and capricious.").

161 F3d 472 (7th Cir 1998).

"Id at 478-79 ("While Quinn may be a 'prevailing party' in that she will have her case remanded, she is not a prevailing party in the truest sense of the word.... [W] are not convinced 
What the proposed legal merits test does, then, is to set up as an explicit standard what some courts already implicitly apply. The legal merits test differs slightly from the Hooper test in that it has applications outside the context of ERISA settlements. The legal merits test also varies somewhat from the analysis in Perlman and Quinn because the proposed test will require courts to speak directly about the basis of their conclusions. Some examples illustrate more clearly how the legal merits test might operate. In the settlement context, this test could exclude a party who argued frivolous positions and successfully settled the case only for the nuisance value. ${ }^{80}$ It also could bar a party that came out ahead on its lawsuit only because the lawsuit prompted some uninvolved third party to step in with relief. ${ }^{\text {s1 }}$ Similarly, in the context where judgment is reached, the legal merits test could bar a party who simply prevailed on procedural grounds. ${ }^{82}$

There are two reasons why courts should adopt the legal merits test. First, the proposed test brings the ERISA definition for prevailing party in line with the definition for the same term suggested by the Supreme Court in the civil rights context and makes the process of determining the prevailing party more internally consistent with other aspects of ERISA jurisprudence. Second, by looking at the merits to determine whether to award attorneys' fees, courts can promote more efficient behavior in ERISA litigation by encouraging settlements where they are rational and by conserving judicial resources.

\section{B. Fitting the ERISA Fee Shifting Doctrine Within the Framework of Existing Law}

The legal merits test is doctrinally superior to the catalyst test in two ways. First, the legal merits test allows ERISA fee shifting to follow better the developments in federal law that implicate how courts should define the prevailing party. In contrast, the catalyst test puts ERISA fee shifting in conflict with the direction of changing law. Second, the legal merits test makes more sense within the context of other rules involved in ERISA fee shifting. It creates a better fit between the test of eligibility and the test of appropriateness for awarding attorneys' fees under ERISA.

\footnotetext{
that Blue Cross' position was totally lacking in justification nor is there any evidence that Blue Cross acted in bad faith.").

"See Poteete v Capital Engineering, Inc, 1999 US App LEXIS 16789, *5-6 (7th Cir) ("Moreover, if a suit is frivolous, and settled merely for its nuisance value, the plaintiff is not even a prevailing party in the technical sense.").

"See Hooper, 37 F3d at 291 (evaluating whether a party who received charitable aid from "a number of people and organizations unrelated to the parties in the lawsuit" can count as a prevailing party).

"See Cefali v Buffalo Brass Co, 748 F Supp 1011, 1019 (W D NY 1990) (considering a petition for fee shifting from a party who presented "misguided and unproductive" claims).
} 


\section{Alignment with Farrar.}

The Supreme Court, in Farrar v Hobby, issued a ruling that implicates the proper standard for prevailing party under ERISA. In that case, the Court considered the petition of a civil rights plaintiff who requested fee shifting after winning only one dollar from his lawsuit for seventeen million dollars. ${ }^{s 4}$ The Supreme Court determined that although the plaintiff prevailed in a technical sense, ${ }^{85}$ he nonetheless deserved nothing in attorneys' fees because he failed to prove the merits of his case. ${ }^{36}$ It held that "to qualify as a prevailing party, a civil rights plaintiff must obtain some relief on the merits of his claim. The plaintiff must obtain an enforceable judgment against the defendant from whom fees are sought, or comparable relief through a consent decree or settlement."

The decision in Farrar signals a departure from the catalyst test in favor of a more stringent standard that takes into account the merits of the case argued by the fee-seeking party in the context of civil rights litigation. In response to Farrar, at least one circuit has explicitly abandoned the catalyst test, ${ }^{89}$ and other courts have expressed reluctance to treat a party with a weak case as a prevailing party. For example, in Poteete $v$ Capital Engineering, Inc, the court held that

506 US 103 (1992).

"See id at 105-09 (describing the facts of the case).

" Id at 112.

"Id at 115 ("When a plaintiff recovers only nominal damages because of his failure to prove an essential element of his claim for monetary relief, the only reasonable fee is usually no fee at all.") (citations omitted).

"Id at 111 (citations omitted).

"See P.G. Szczepanski, Note, For a Few Dollars Less: Equity Rides Again in the Denial of Section 1988 Attorney's Fees to a Prevailing Plaintiff in Farrar v. Hobby, 5 Temple Polit \& Civ Rts L Rev 219, 219 (1996) ("Farrar has also been interpreted as having eliminated the catalyst theory under which many civil rights plaintiffs are awarded Section 1988 fees"); Trotter, 80 Va L Rev at 1446 (cited in note 63) ("Although the Court did not address Farrar's implications for catalytic recovery, the actual consequence of the decision still seems inescapable: A plaintiff can no longer prevail through the catalyst theory alone.").

"See Statewide Reapportionment Advisory Committee v Beasley, 99 F3d 134, 136 (4th Cir 1996) (noting that the catalyst test no longer applied after Farrar), cert denied, 520 US 1166 (1997). See also $S-1$ and $S-2$ by and through $P-1$ and P-2 $v$ State Board of Education of North Carolina, 6 F3d 160, 168-69 (4th Cir 1993) (Wilkinson dissenting) ("There is no way, however, that Farrar and a broad 'catalyst theory' of attorneys' fees recovery can be reconciled."), adopted as the opinion of the court upon rehearing en banc, 21 F3d 49,51 (4th Cir 1994) (per curiam). For a general background of $S-1$ and S-2, see Martin Patrick Averill, "Specters" and "Litigious Fog"?: The Fourth Circuit Abandons Catalyst Theory in S-1 and S-2 by and through P-1 and P-2 v. State Board of Education of North Carolina, 73 NC L Rev 2245, 2247-51 (1995).

${ }^{\circ}$ See NAACP, Detroit Branch v Detroit Police Officers Association, 46 F3d 528,530 (6th Cir 1995 ) (citing $S-1$ and $S$-2 for the proposition that a plaintiff arguing a case without merits cannot recover attorneys' fees); Hooper, 37 F3d at 295 (Manion concurring) (noting that Farrar changed the requirements for a prevailing party). But see Marbley v Bane, 57 F3d 224, 234 (2d Cir 1995) (arguing that Farrar does not invalidate the catalyst test); Zinn v Shalala, 35 F3d 273, 276 (7th Cir 1994) (indicating the continuing viability of the catalyst test after Farrar); Craig v Gregg County, 
[t] here is no novelty in distinguishing between a party in whose favor judgment is rendered and a party who obtains meaningful relief. A plaintiff who sues for $\$ 1$ billion and receives a judgment for 1 is technically the prevailing party, but he will be awarded zero attorneys' fees under a statute that makes the award of fees to a prevailing party a matter of course. Moreover, if a suit is frivolous, and settled merely for its nuisance value, the plaintiff is not even a prevailing party in a technical sense.

Farrar enhances the doctrinal basis for adopting the legal merits test in ERISA fee shifting. Both Farrar and the proposed test focus on the merits of the underlying claim when determining whether a party is prevailing and entitled to receive attorneys' fees. It might not be clear at first, however, why a rule under civil rights law should have anything to do with the definition of prevailing party under ERISA. After all, courts applying ERISA fee shifting in the past have strenuously resisted analogizing ERISA with civil rights laws for the purpose of finding a presumption favoring the recovery of fees. ${ }^{53}$ There are two reasons why Farrar should guide the prevailing party standard for ERISA. First, to the extent that attorneys' fees should be awarded more liberally under civil rights laws, it does not make any sense for ERISA to have more lenient requirements for the prevailing party. With Farrar as a point of reference for civil rights laws, the prevailing party test under ERISA should be at least as demanding if not more so.

Second, while the substantive policy differences between civil rights laws and ERISA justifies having different presumptions for fee shifting, it does not require dissimilar definitions for the prevailing party. ${ }^{\text {s. }}$ There is no reason why, on a definitional issue such as this one, an identical term-prevailing party-should mean different things.

Texas, 988 F2d 18, 21 (5th Cir 1993) (acknowledging the conflict between Farrar and the catalyst test).

1999 US App LEXIS 16789 (7th Cir).

"Id at *5-6 (citations omitted).

"See Phelps, 64 Geo Wash L Rev at 851 (cited in note 11) (commenting that some courts "find the analogy to civil rights statutes inappropriate for ERISA fee award determinations"). See also Armistead v Venitron Corp, 944 F2d 1287, 1302-03 (6th Cir 1991) (declining to import a presumption for fee shifting from civil rights statutes to ERISA); Gray v New England Telephone and Telegraph Co, $792 \mathrm{~F} 2 \mathrm{~d} 251,259$ (1st Cir 1986) (declaring that the presumption favoring fee shifting under litigation involving civil rights statutes does not apply to ERISA).

" See Armistead, 944 F2d at 1303 (holding that ERISA lacks the same level of public importance as civil rights litigation and should have a less liberal standard for fee shifting).

"See Perlman, 990 F Supp at 1041 ("In ERISA cases, a 'prevailing party' is determined using the same standard set forth under 42 USC $\S 1988 . ")$.

* See Phelps, 64 Geo Wash L Rev at 850 (cited in note 11) ("Although no such explicit legislative history is available for ERISA's fee shifting provision, the statutory language is nearly identical to civil rights law."); Bertino, 41 Cath U L Rev at 877-78 (cited in note 8) (observing 
These same reasons demonstrate why courts should reject the catalyst test. Under the catalyst test, ERISA fee shifting would have a more lenient standard than civil rights fee shifting, contrary to the ordering of policy objectives expressed by courts. Also, the catalyst test would create a situation where similar terms have disparate meaning under different laws, even though these terms operate for the same purpose. In sum, the courts should choose the legal merits test over the catalyst test simply because it is more consistent with federal law after Farrar.

\section{Internal consistency.}

At the outset, an argument can be made that the courts should adopt the legal merits test simply because it provides for a better alternative to the lack of uniformity in the status quo. Compared to the current state in which courts apply different and contradicting tests for determining the prevailing party, commitment to any uniform rule might conceivably enhance some rule of law quality of ERISA fee shifting. But this argument is not extremely convincing-it offers no reasons to specifically choose the legal merits test over any other rule. Generally, the legal merits test offers two advantages over the catalyst test for identifying the prevailing party. First, it conforms better with the statutory text of the ERISA fee shifting provision. Second, the legal merits test allows for more consistency between the definition of prevailing party and the Eaves factors.

One well accepted canon of statutory interpretation stipulates that any reading of a law should not contradict the law's textual language. $^{100}$ In terms of the ERISA fee shifting provision, the language of the statute clearly leaves open the possibility that courts will award at-

that civil rights statutes allow fee shifting to both plaintiffs and defendants in a way similar to ERISA).

See note 94 and accompanying text.

see Part II.B.

"See J. Harvie Wilkinson III, Toward a Jurisprudence of Presumptions, 67 NYU L Rev 907 , 908 (1992) (noting the advantages of clear rather than conflicted and confused law); William N. Eskridge, Jr., and Phillip P. Frickey, Statutory Interpretation as Practical Reasoning, 42 Stan L Rev 321,339 (1990) (arguing for the appeal of the rule of law value that people should know the law); Antonin Scalia, The Rule of Law as a Law of Rules, 56 U Chi L Rev 1175, 1179 (1989) ("Even in simpler times uncertainty has been regarded as incompatible with the Rule of Law."); Richard A. Posner, The Federal Courts: Crisis and Reform 248 (Harvard 1985) (explaining that the law cannot "induce people to behave in particular ways ... if it is constantly changing directions").

${ }^{30}$ See Connecticut National Bank v Germain, 503 US 249, 253-54 (1992) (indicating that the canons of construction disfavor interpretations that make language in a statute superfluous and commenting that the text of a law should be followed whenever it is unambiguous). See also Antonin Scalia, A Matter of Interpretation: Federal Courts and the Law 16 (Princeton 1997) ("[W]hen the text of the statute is clear, that is the end of the matter."); Scalia, 56 U Chi L Rev at 1183 (cited in note 99) (arguing that judges must always find some basis for their interpretations in the text of the law); Frank H. Easterbrook, Statutes' Domains, 50 U Chi L Rev 533, 544-51 (1983) (advocating the "clear statement" principle in statutory interpretation). 
torneys' fees to either the plaintiff or the defendant. ${ }^{101}$ Accordingly, interpretive convention demands that the prevailing party standard allows for both parties to have a chance at recovering the cost of their fees. The catalyst test fails this condition because it precludes the defendant from successfully petitioning for fees. Under the catalyst test, the party seeking fees must demonstrate that it took some action that caused a realization of gain. ${ }^{102}$ The ERISA defendant, by the nature of her position on the defense, often has a hard time making this showing. What serves as an easy test for the plaintiff then poses a tremendous challenge for the defendant. ${ }^{103}$ In contrast, the legal merits test relies only on an examination of the strength of the fee-seeking party's case, and does not have a bias against the plaintiff or the defendant. Even though the ERISA fee shifting policy discourages awarding the defendant attorneys' fees in many instances, the legal merits test is nonetheless a more appropriate standard because it at least maintains the possibility that the defendant might obtain recovery of fees, ${ }^{104}$ preserving cohesion between the text of the law and the applied standard.

The legal merits test also offers greater consistency with the Eaves factors. ${ }^{105}$ The catalyst test presents a very minimal barrier to the party seeking to qualify as a prevailing party, and it almost never eliminates fee applicants from the process. ${ }^{106}$ Applying this test, courts frequently create the strange situation in which they consider a party's

${ }^{m}$ See 29 USC $\$ 1132(\mathrm{~g})(1)$ (authorizing courts to award "a reasonable attorneys' fee and costs of action to either party"). See also Little $v$ Cox's Supermarket, 71 F3d 637, 644 (7th Cir 1995) (awarding attorneys' fees to defendant under ERISA); Gray $v$ New England Telephone \& Telegraph Co, 792 F2d 251, 258-59 (1st Cir 1986) (stating that ERISA attorneys' fees can be awarded to the defendant as well as to the plaintiff).

${ }^{103}$ See McManus v Gitano Group, Inc, 59 F3d 382, 384 (2d Cir 1995) (arguing that fee shifting requires a demonstration of causation between the litigation and the obtaining of some benefit); Hamilton $v$ Bank of New York (Delaware), 1995 US Dist LEXIS 10464, *12-13 (D Del) (finding that the plaintiff's decision to sue was causal in the recovery of benefits); Petro $v$ Flintkote Co, 633 F Supp 10,11 (N D Ohio 1986) ("[A] plaintiff may qualify as a prevailing party if the lawsuit is casually [sic] related to securing the relief obtained.").

${ }^{100}$ See Dobbs, 1986 Duke L J at 450 (cited in note 52) ("Most federal courts have used a 'generous formulation' to give the plaintiff prevailing party status."); Trotter, 80 Va L Rev at 1436 (cited in note 63) (commenting that the catalyst test is almost always applied for plaintiffs to recover attorneys' fees from defendants).

is See Glennie v Abitibi-Price Corp, 1996 US Dist LEXIS 13366, *2-5 (W D Mich) ("Defendants, as prevailing parties in this lawsuit, may be awarded their costs. . . [B] ecause defendants prevailed, the relative merits of their positions weighs in favor of an award of costs.").

For a review of the Eaves factors, see text accompanying note 23.

${ }_{1 \%}$ Virtually any plaintiff can show that it prevailed under the catalyst test by showing that it obtained some relief after the commencement of its lawsuit. See Trotter, 80 Va L Rev at $1439-40$ (cited in note 63) (explaining that the catalyst test can be satisfied even if the lawsuit resulted in "change merely because administrators preferred to avoid the nuisance and expense of litigation"); Dobbs, 1986 Duke L J at 453 (cited in note 52) (noting that courts have found some plaintiffs to be prevailing parties even when the relief obtained came not from defendants, but from an administrative or legislative act). 
petition for fee shifting even though the party has no realistic chance of obtaining attorneys' fees. This is a wasteful use of judicial resources and a meaningless exercise. The legal merits test is superior then in that it allows a better filtering of candidates for fee shifting. While not every party who passes the legal merits test will satisfy the Eaves factors-even the most meritorious party cannot recover, after all, if the other party has no ability to pay-the legal merits test at least does a better job of clearing out those parties that clearly have no prospect of recovering fees.

\section{Encouraging Settlements and Judicial Savings}

As a consequence of choosing the legal merits test over the catalyst test, fewer litigants will qualify to receive attorneys' fees. This result certainly seems logical. The legal merits test poses a greater barrier for the party seeking compensation of fees. Applying the proposed test, courts must consider the merits of the claims argued by the party requesting attorneys' fees. In contrast, under the catalyst test the party seeking fees need only show that she benefited as a result of the litigation process. ${ }^{107}$

Consider the facts of Hooper. Depending on the test employed by the court, two outcomes are possible. If the Hooper court had adhered to the catalyst test, it could have concluded that the plaintiff satisfied the standard for prevailing party. ${ }^{108}$ By looking to the legal merits of the case argued by the plaintiff, however, the Hooper court resolved that the plaintiff in fact should not be eligible for fee shifting. ${ }^{109}$ The decision in Quinn accommodates a similar analysis. Like Hooper, the Quinn court could have found that the plaintiff met the prevailing party requirement if it had applied the catalyst test. ${ }^{10}$ Instead, the court in Quinn looked beyond what the plaintiff technically achieved and held that the plaintiff had not made a sufficiently convincing showing of the merits of her case to entitle her to fees."

The more rigorous standard of the legal merits test points to two reasons for adopting it and rejecting the catalyst test. First, by de-

${ }^{\prime \prime}$ See McManus v Gitano Group, Inc, 59 F3d 382,384 (2d Cir 1995) ("Recovery of fees on a catalyst theory requires an applicant to demonstrate a causal connection between the litigation and the recovery of benefits."). See also Trotter, $80 \mathrm{Va} \mathrm{L} \mathrm{Rev} \mathrm{at} \mathrm{1433-37} \mathrm{(cited} \mathrm{in} \mathrm{note} \mathrm{63)} \mathrm{(de-}$ tailing the general description and background of the catalyst test).

${ }^{100}$ Hooper, 37 F3d at 292 (conceding the possibility that the plaintiff caused the recovery by initiating an ERISA lawsuit).

${ }_{t \infty}$ Id at 294-95 (noting that the plaintiff failed to provide adequate evidentiary support for his case and that the defendant offered to help the plaintiff gratuitously).

"Quinn, $161 \mathrm{F3d}$ at 479 (suggesting that the plaintiff prevailed in her case "in some sense of the term").

"' Id at 478-79 (holding that the plaintiff did not persuasively show that her case had sufficient legal merits). 
manding more from the party seeking attorneys' fees, the legal merits test affects the decision of ERISA litigants to settle. Specifically, the more difficult conditions make it harder for a party to qualify as a prevailing party and lower the overall expectation for fee shifting. Such a reduction in the general prospects for awards of attorneys' fees compels ERISA litigants to alter their settlement calculus, leading them more often to choose to settle cases when efficiency dictates. Second, the legal merits test limits the wasteful consumption of legal resources by filtering out the volume of illegitimate parties that courts must consider for fee shifting.

\section{Encouraging efficient settlements.}

In the course of ordinary settlement negotiations, the parties communicate information about the relative strengths of their positions through their offers or demands. ${ }^{112}$ This posturing tends to improve the chances of reaching a compromise. As parties make offers or demands, they send signals that mitigate the possibility of false confidence preventing settlement. ${ }^{133}$ Of course, not all parties communicate truthfully. Some might misrepresent their positions by offering less or demanding more than their case deserves in the hopes that this bluffing will mislead their opponents into greater concessions. ${ }^{114}$ Issuing false signals in such instances undermines the settlement process and can result in wasteful delays or failures in bargaining."

Fee shifting exacerbates the problem of bluffing by increasing the signal strength of parties who choose to negotiate dishonestly. The availability of attorneys' fees allows the bluffing party not only to communicate her belief about winning the case, but her certainty in prevailing in the fee dispute, effectively raising the amount at stake. ${ }^{116}$

${ }^{n 2}$ See Richard A. Posner, Economic Analysis of Law 608 (Aspen 5th ed 1998) (describing settlement as a process in which parties signal to each other how confident they feel about their respective cases to lend credibility to their demands and offers).

"See id ("TT]he settlement process itself is likely to reduce the divergence of estimates."); Robert Cooter and Thomas Ulen, Law and Economics 486 (Scott, Foresman 1988) ("Thus, one source of trials is optimism: when parties think they will win at trial, neither will concede when bargaining.").

it See A. Mitchell Polinsky, An Introduction to Law and Economics 112-13 (Little, Brown 2d ed 1989) (arguing that parties may act strategically and bluff in settlement negotiations).

"See Keith N. Hylton, Fee Shifting and Incentives to Comply with the Law, 46 Vand L Rev $1069,1084-85$ (1993) (noting that bluffing by parties trying to capture a larger portion of the settlement surplus can lead to negotiation failures); Eric Talley, Liability-Based Fee-Shifting Rules and Settlement Mechanisms Under Incomplete Information, 71 Chi Kent L Rev 461, 465 (1995) ("This incentive to misrepresent one's private information can be wasteful, for it increases the probability of bargaining failure or delay, even when it is obvious to all that there are immediate gains from settlement.").

"See Talley, 71 Chi Kent L Rev at 466 (cited in note 115) ("Now, the bluffing party signals information not only about the relative strength of her case, but also about the likelihood that she will ultimately have to bear litigation costs.") (emphasis omitted). 
While fee shifting does not modify the incentives of parties to bluff per se, it certainly makes the problem of bluffing more serious because it fosters greater divergence in the parties' offers and demands and increases the possibility of settlement failure. ${ }^{117}$

Although the statutory fee shifting provision under ERISA means that the opportunity for awarding attorneys' fees will always exist to some degree in ERISA litigation, the legal merits test lessens the adverse impact that fee shifting can have on settlements. By making the prevailing party standard more demanding and reducing the general expectation of fee shifting, ${ }^{118}$ the legal merits test eliminates some of the transaction costs that block parties from settling cases because courts can remove from consideration for fee shifting those parties with unmeritorious claims. ${ }^{119}$ Thus, the legal merits test eliminates fee shifting as a factor in a significant portion of the cases. ${ }^{120}$ In contrast, the catalyst test preserves the possibility of fee shifting for a

"in It is possible that fee shifting could even encourage bluffing in the ERISA context, at least for the plaintiff with an unmeritorious case. Such a plaintiff, understanding that the courts would be unlikely to award attorneys' fees to the defendant under ERISA, might consider the costs of a failed negotiation (going to trial) the same as the costs for accepting an unfavorable settlement. In such a situation, the plaintiff with weak claims might opt to bluff aggressively because she faces a low probability of having to pay for this strategy. See id at $466 \& \mathrm{n} 17$ (arguing that a weak party will choose to bluff because the truth would force it to accept an unfavorable settlement anyway).

"See notes 73-82 and accompanying text.

"1 Although it may initially appear ambitious to expect courts to distinguish between meritorious and frivolous cases, it is actually not so difficult for courts to do so in practice. Indeed, courts already make such distinctions as a matter of course in many other contexts of law. See, for example, Cooter \& Gell v Hartmarx Corp, 496 US 384, 393 (1990) (identifying certain kinds of cases as "baseless"); Hayduk v Lanna, 775 F2d 441, 444 (1st Cir 1985) (concluding that the plaintiff filed a frivolous securities fraud lawsuit); Semegen $v$ Weidner, 780 F2d 727, 731 (9th Cir 1985) (same). While it must be acknowledged that courts will have a harder time making a determination of frivolousness in some cases, there is nonetheless little reason to believe that courts cannot perform that task. For a general discussion, see A. Mitchell Polinsky and Daniel L. Rubinfeld, Sanctioning Frivolous Suits: An Economic Analysis, 82 Georgetown L J 397 (1993); William C. Baskin III, Note, Using Rule 9(b) to Reduce Nuisance Securities Litigation, 99 Yale L J 1591 (1990); John W. Wade, On Frivolous Litigation: A Study of Tort Liability and Procedural Sanctions, 14 Hofstra L Rev 433 (1986).

${ }^{120}$ Of course, there is no way to compute with precision just how many fee applicants the legal merits test would filter out. At the very least, the legal merits test would qualify fewer candidates for fee shifting than the catalyst test and should produce some relative gains. See notes $80-$ 82 and accompanying text. It should be noted that the legal merits test facilitates settlement in the cases where the parties most often avoid litigation. Parties should choose settlement in cases that do not involve mutual optimism, that is, cases where one party has a much stronger or more meritorious position. See Posner, Economic Analysis of Law at 610 (cited in note 112) ("In general, then, litigation will occur only if both parties are optimistic about the outcome of the litigation."). The legal merits test most effectively precludes fee shifting from imposing transaction costs on settlements for these types of cases by making it clear that the party with the corresponding unmeritorious position has no chance of receiving attorneys' fees. 
larger pool of candidates and leaves open the opportunity for fee shifting to derail settlement negotiations.

The legal merits test reduces the problem of transaction costs in two ways. ${ }^{12}$ First, it diminishes the grounds for disagreement or concern over liability for fees that can potentially prevent parties from settling cases. ${ }^{123}$ Accordingly, the legal merits test allows ERISA litigants to settle cases with only nuisance value or to act charitably without having to worry that such decisions will expose them to fee shifting later.'

Second, the legal merits test reduces the transaction costs associated with bluffing as a bargaining strategy. Bluffing becomes a less effective strategy when courts take into account the legal merits of the underlying claim in awarding attorneys' fees. Litigants can still opt to misrepresent the strengths of their cases, but the signal they communicate would carry substantially less meaning because the courts in every case will apply an independent review of the merits. ${ }^{125}$ Knowing that the courts will require a more rigorous standard for fee shifting, parties will take less seriously threats by their opponents that the courts will award attorneys' fees in their favor. In contrast, the catalyst test still provides opportunity for bluffing parties to try to scare their opponents into conceding to favorable settlements because the courts

\footnotetext{
${ }^{12}$ See note 117 and accompanying text.

${ }^{12}$ Incidentally, these reasons also explain why it is not enough to expect the Eaves test to provide the incentives for efficient behavior in ERISA litigation. Although the Eaves test will affect the incentives of parties to seek settlement in some contexts, the prevailing party test nonetheless plays a significant role in the settlement calculus of litigants. Using the catalyst test might make fee shifting more available, increasing the potential for bargaining failures through the added transaction costs of fee shifting. On the other hand, the legal merits test limits the awarding of attorneys' fees and encourages settlement in a way that the Eaves test independently cannot.

${ }^{20}$ For example, some parties might have an aversion to settlement if they also worry about having to pay attorneys' fees. They might also refuse settlement if they dispute their liability for fee shifting.

${ }^{12}$ This point most clearly demonstrates the advantage of the legal merits test over the catalyst test. Under the catalyst test, a party might refuse to settle even frivolous cases because such a settlement might allow the opposing party to claim that the bargain made her better off than before the legal action. See Hamilton v Bank of New York (Delaware), 1995 US Dist LEXIS 10464, *6-7,*12-13 (D Del) (recognizing the plaintiff as a prevailing party even though she settled with the defendant for reasons unrelated to the merits of her contention and did not establish the liability of the defendant). In contrast, allowing the courts to consider the merits behind the parties' positions would obviate concerns of the party desiring to rid herself of a frivolous case or settle gratuitously. See Hooper v Demco, Inc, 37 F3d 287, 292-95 (7th Cir 1994) (rejecting the plaintiff's demand for attorneys' fees because his case lacked merit and the defendant agreed to help only out of charitable instincts).

${ }^{18}$ It is possible that parties in this context will move toward more honest disclosures about the merits of their cases. If bluffing has no purpose, then parties with good claims will want to signal the quality of their cases to their opponents. Such disclosures would enhance the prospects for settlement. See Posner, Economic Analysis of Law at 608 (cited in note 112) (discussing how disclosures through bargaining improves the chances for parties reaching settlement).
} 
are not present to serve a policing function by reviewing the merits of the parties.

\section{Conserving judicial resources.}

Apart from affecting the rate of settlements, the legal merits test also saves judicial resources. The availability of indemnification for legal expenses invites the consumption of judicial resources as parties litigate over the fees issue itself. ${ }^{126}$ More precisely, the process of determining whether a party should receive attorneys' fees and what amount of fees is reasonable is costly for courts to undertake. ${ }^{127}$ Also, litigation over fees will likely generate more appeals, and this further expends valuable judicial resources. ${ }^{12 s}$ Finally, the prospect of indemnity for the costs of legal actions encourages parties to overspend in their litigation efforts because parties are less likely to have to internalize the costs of their own behavior. ${ }^{129}$

The legal merits test allows courts to avoid the costs of proceeding with the Eaves analysis when it is clear that the party asking for fee compensation has not achieved any gains on the basis of a meritorious case. ${ }^{130}$ By disqualifying such parties from consideration for fee shifting, courts can also effectively erase the need for secondary fees litigation by the parties in an ERISA lawsuit. ${ }^{131}$ Finally, with a dimmer prospect for having someone else pay the costs of legal actions, parties will have the incentive to spend more rationally in their ERISA lawsuits.

${ }^{125}$ See Harold J. Krent, Explaining One-Way Fee-Shifting, 79 Va L Rev 2039, 2083 (1993) (emphasizing that there are "significant hidden costs" involved with litigation over the awarding of attorneys' fees); Dobbs, 1986 Duke L J at 438 (cited in note 52) (arguing that fee shifting causes courts and parties to devote public and private resources to fee litigation). See also $S-1$ and S-2 by and through $P-1$ and P-2 v State Board of Education of North Carolina, 6 F3d 160, 171 (4th Cir 1993) (Wilkinson dissenting) ("Too frequently, legal battles over attorneys' fees merely add another round of protracted litigation to what already has been protracted litigation on the merits of a claim. This collateral litigation over attorneys' fees is often more heated, more arcane, and over far higher monetary stakes than the underlying lawsuit.") (citation omitted), adopted as the opinion of the court upon rehearing en banc, 21 F3d 49 (4th Cir 1994) (per curiam).

"See Posner, Economic Analysis of Law at 629 (cited in note 112) ("Indemnity creates satellite litigation, and such litigation can be quite costly.").

see id ("Indemnity is likely to increase the appeal rate-a troublesome consequence because ... appellate courts are the bottleneck of a judicial system.").

"See id ("The existence and costs of satellite indemnity litigation make it all the more uncertain that indemnity actually reduces the amount and aggregate costs of litigation by forcing each party to internalize the other party's litigation cost.").

${ }^{100}$ See Farrar v Hobby, 506 US 103, 117 (1992) (O'Connor concurring) (arguing that courts will avoid "the usual complexities involved in calculating attorney's fees" when they bar parties whose winnings are purely technical or de minimis from eligibility for fee shifting).

"1ne legal merits test has a better chance at reducing secondary litigation over fee shifting than the catalyst test. See $S-1$ and $S-2,6$ F3d at 171 (Wilkinson dissenting) ("[T]he catalyst theory of fee recovery engenders confusion and unnecessary litigation. By providing a clear rule for achieving prevailing party status, Farrar promises to reduce litigation over attorneys' fees."). 


\section{CONCLUSION}

The federal courts should adopt the legal merits test for determining prevailing parties in the context of ERISA fee shifting. This standard furthers cohesion within the ERISA fee shifting doctrine and creates a better fit between the definition of a prevailing party under ERISA and under other federal statutes that also allow attorneys' fees awards. The proposed prevailing party test also encourages more efficient decisionmaking by ERISA litigants and allows the courts to save judicial resources. Accordingly, the legal merits test represents an improvement over the current confused and conflicted collection of prevailing party standards under ERISA. 


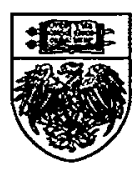

